BORIS TOMANIĆ, MA, Research Assistant

Institute for Contemporary History

Belgrade, Republic of Serbia

borisbox62@gmail.com

originalan naučni rad

UDK: 341.322.5(497.11)"1941"

primljeno: 21. novembar 2018.

94(497.11)"1941/1945":930(497.11)

prihvaćeno: 9. oktobar 2019.

https://doi.org/10.29362/ist20veka.2020.1.tom.83-106

\title{
MASS SHOOTINGS IN KRAGUJEVAC DURING AND AFTER WORLD WAR II (1941-1945) TESTIMONIES AND MEMORIZATION*
}

\begin{abstract}
From the beginning of World War II, mass and continuous shootings were carried out in Kragujevac, a city in central Serbia. First, German soldiers executed over 2,790 civilians in Šumarice on October 1941. Later, in November of the same year, the German authorities formed the Metino Brdo camp, where partisan fighters and civilians were tortured, killed, and deported until June of 1942. Then, the German soldiers murdered hundreds of civilians in retaliation near the Military Technical Institute in Kapislana, from the autumn of 1942 until the autumn of 1943. After the liberation of Serbia in the autumn of 1944, the Communist authorities started with executions of ideological and political enemies on Metino Brdo and Kapislana. In this article, we will attempt to perceive this issue from a new angle, by analyzing archival materials, testimonies and memories of survivors, recent relevant literature, and relying on other disciplines close to historiography.
\end{abstract}

KEYWORDS: Kragujevac, Serbia, World War II, German Soldiers, Communist Authorities, Mass Shootings

\section{Introduction}

Yugoslavia came out of World War II with about 1,100,000 victims. ${ }^{1}$ In addition to crimes carried out by the occupation forces (Germany, Italy, Hunga-

\footnotetext{
* This article is part of the project called Serbian Society in the Yugoslav State in the 20th Century: Between Democracy and Dictatorship (177016) financed by the Ministry of Education, Science, and Technological Development of the Republic of Serbia.

${ }^{1}$ About the losses of the Yugoslav population in World War II more: Vladimir Žerjavić, Gubici stanovništva Jugoslavije u Drugom svjetskom ratu (Zagreb: Jugoslavensko viktimološko društvo, 1989); Животије Ђорђевић, Губиии становништва Југославије у Другом светском рату (Београд: АБЦ-Графика, 1997); Bogoljub Kočović, Žrtve Drugog svetskog rata u Jugoslaviji, (Sarajevo: Svetlost, 1990); Nenad Lajbenšperger, „Presenting and Establishing the Number of Yugoslav Casualties of World War II from Liberation until 1951“, Токови историје, бр. 3, (2017), 143-166; Драган
} 
ry, Bulgaria, Albania), many casualties were the product of ideological, religious, and racial differences. In the Independent State of Croatia, the victims were Jews, Serbs and communists; in Kosovo and Metohija the Albanians, with the help of Germany and Italy, conducted their criminal policy; while the civil war between the communists and the royalists took the most lives in Serbia. ${ }^{2}$

Through the example of Kragujevac, a city in central Serbia, which endured many horrors, we will try to answer the following questions: Was there any continuity in the crimes committed in the period between 1941 and 1945 ? To what extent were the crimes committed by the occupation forces and to what extent were they committed by the communists? Did the locations of the killing fields during and after World War II remain the same? What was the social status of the victims? Were the crimes committed for ideological, religious, or other reasons? Which crimes were raised to the level of myth and which ones were consigned to oblivion? Is there a myth about the number of victims? What is the public opinion regarding the crimes committed in Kragujevac and what is the judgment of historiography?

In this document we will analyze the three best known murder sites in Kragujevac and its surroundings. Through oral testimonies and written sources, we will also show how public opinion has been shaped from the end of World War II to the present about the crimes committed in Šumarice, Metino Brdo and Kapislana. ${ }^{3}$

$* * *$

After World War I, Germany was preoccupied with its internal problems and was not very interested in Yugoslavia. After stabilizing its internal conditions and in search of raw materials, Germany gradually started turning its attention toward Southeast Europe and Yugoslavia. It also had territorial aspirations toward this part of Europe. Thus, Franz von Papen, then ambassador of the German Reich in Austria, told a US diplomat in Vienna in 1934 that "all of Southeastern Europe, all the way to Turkey, was Germany's sphere of influence and that it is entrusted with the mission to facilitate German economic and political control over this whole region". ${ }^{4}$ So, the plan for enslaving Southeast Europe in general and for Yugoslavia in particular, had already been made by

Цветковић, „Холокауст као екстремни облик страдања цивила окупиране Србије - нумеричко одређење и квантитативна анализа", Токови историје, бр. 2, (2018), 89-118.

${ }^{2}$ More: Венцеслав Глишић, Терор и злочини нацистичке Немачке у Србији 1941-1944 (Београд: Рад, 1970); Dušan Lukač, Treći Rajh i zemlje jugoistočne Evrope. Treći deo, 1941-1945 (Beograd, Ljubljana: Vojnoizdavački zavod, Balkanološki institut SANU, Prosveta, RadPartizanska knjiga, 1987); Branko Petranović, Istorija Jugoslavije 1918-1988. II knjiga. Narodnooslobodilački rat i revolucija 1941-1945 (Beograd: Nolit, 1988); Branko Petranović, Srbija u Drugom svetskom ratu: 1929-1945 (Beograd: Vojnoizdavački i novinski centar, 1992).

3 Šmarice was the field and today it is the memorial park on the west side of Kragujevac, Metino Brdo is the hill on the south end of the city and Kapislana was the part of the Military Technical Institute, it is a Serbian word for ammunition storeroom. Today, Kapislana is in the circle of the "Fiat" automobile factory on the south side of the city.

${ }^{4}$ Izveštaj Jugoslovenske Državne komisije za utvrđivanje zločina okupatora i njihovih pomagača Međunarodnom Vojnom sudu u Nürnbergu (Beograd, Zagreb: Tipografija, 1947), 8. 
1934. Aspirations toward Southeast Europe were also obvious in Hitler's interview with Italian Foreign Minister Galeazzo Ciano on August 13, 1939, in which Hitler proposed that Italy attack Yugoslavia while Germany would attack Poland. The plan for the complete annihilation of Yugoslavia was already put on the agenda, and it was postponed only because of the military weakness of Italy. Along with these statements, the Government of the Third Reich and the Nazi Party (NSDAP) secretly started to organize the German minority in Yugoslavia (members of Kulturbund and Volksdeutsche) and the "fifth column". While the government and the party were preparing the attack and occupation of Yugoslavia, Hitler was using every opportunity to declare on behalf of the government, the party, and even of all Germany, that Yugoslavia could count on them as loyal friends. ${ }^{5}$

After the outbreak of World War II, because of the possibility of an attack on the Soviet Union and the beginning of a two-front war, the Third Reich potentially tried to pacify conditions in Southeast Europe by offering the Treaty of Accession to the Tripartite Pact, targeting a second-rate role for the Balkan states in the new division of Europe in which they would represent a source of raw materials and cheap labor for Germany. Yugoslavia was forced by external and internal problems to enter the Tripartite Pact on March 25, 1941, but the Pact and the Government were overthrown after two days, and conflict was inevitable. ${ }^{6}$

Yugoslavia was attacked on April 6, 1941, without any previous warning or declaration of war. This attack, under the codename "Punishment", began with the aerial bombing of unprotected cities, especially Belgrade, although the capital of Yugoslavia had been declared an open, undefended city before the beginning of the war. ${ }^{7}$

In the "Blitzkrieg", capitulation was signed on April 17, 1941. Germany immediately carried out the occupation and began taking apart the territory of Yugoslavia. Some parts of this territory were distributed to their allies: Hungary, Bulgaria and Italy. The territory of Croatia, Bosnia and Herzegovina and Syrmia came under the newly-established puppet state of the Independent State of Croatia, while the northern parts of Slovenia: Upper Carniola, Lower Styria and the Yugoslav part of Carinthia became a part of Germany. Banat had a spe-

\footnotetext{
${ }^{5}$ Izveštaj Jugoslovenske Državne komisije..., 8-10; More: Nikola Živković, Ratna šteta koju je Nemačka učinila Jugoslaviji u Drugom svetskom ratu (Beograd: Institut za savremenu istoriju, 1974); Zoran Janjetović, Nemci u Vojvodini (Beograd: Institut za noviju istoriju Srbije, 2009); Dušan Lukač, Treći Rajh i zemlje jugoistočne Evrope. Prvi deo, 1933-1936 (Beograd, Ljubljana: Vojnoizdavački zavod, Balkanološki institut SANU, Prosveta, Rad, Partizanska knjiga, 1982); Dušan Lukač, Treći Rajh i zemlje jugoistočne Evrope. Drugi deo, 1937-1941 (Beograd, Ljubljana: Vojnoizdavački zavod, Balkanološki institut SANU, Prosveta, Rad, Partizanska knjiga, 1982); Milan Ristović, Nemački novi poredak i Jugoistočna Evropa 1940/41-1944/45, planovi o budućnosti i praksa (Beograd: Službeni glasnik, 2005).

${ }^{6}$ More: Momčilo Pavlović, Ivana Pantelić, ur., 27. mart 1941, sedamdeset godina kasnije (Beograd: Institut za savremenu istoriju, 2012); Branko Petranović, Nikola Žutić, prir., 27. mart 1941, tematska zbirka dokumenata (Beograd: NICOM, 1990).

${ }^{7}$ Velimir Terzić, Slom Kraljevine Jugoslavije 1941. Uzroci i posledice poraza, 2 (Beograd, Ljubljana-Beograd, Titograd: Narodna knjiga, Partizanska knjiga, Pobjeda, 1982), 247-303.
} 
cial status and was under German administration. With the exception of the parts occupied by Bulgaria and Italy, Serbia represented an administrative entity, which, as an occupied territory, was managed by the German Military Commander. In that sense, the German war crimes in Yugoslavia pertain to the territory of Serbia and northern Slovenia and Bosnia and Herzegovina, where larger operations were conducted against the Partisan resistance from 1942, as well as in the areas that were taken after the capitulation of Italy in September of 1943, (Dalmatia and Lika). ${ }^{8}$ Serbs were labeled as the main offenders, who, according to Hitler's claims, were the initiators of World War I and the cause of Yugoslavia's non-accession to the Tripartite Pact.

Immediately after the invasion, a strong military-administrative system was instituted, which was divided into District Military Commands (Feldkommandantur), County Military Commands (Kreiskommandantur) and Municipality Military Commands (Ortskommandantur). The German authorities introduced rigorous measures to punish each offence brutally, most often by retaliation against the innocent civilian population. Even during the April War, the invader showed his true face. Thus, by the order of Field Marshal Maximilian von Weichs and due to death of several German soldiers, more than 100 people were shot dead on April 12, 1941 in Alibunar and on April 23, 1941, in Zrenjanin and Pančevo, in the Banat region. It was made known from then on that 100 Serbs would be shot for one German killed, but this order was not strictly enforced. Then came Field Marshal Wilhelm Keitel's order of September 16, 1941, for 100 hostages to be shot for every German soldier killed and 50 for every German soldier wounded. Even after such a brutal order, the attacks on German soldiers continued, but the retaliations included a smaller number of hostages than the order stipulated. ${ }^{9}$

In the first months of the occupation, two antifascist resistance movements were created, the most famous of which were the Partisans of Josip Broz Tito and the Royalists (Chetniks) of Draža Mihailović. By constant guerrilla attacks through mid-September of 1941, large areas of free territories had been created in Serbia. The Third Reich with its three infantry divisions: the 704th, 714th, and 717th, which consisted of older soldiers who were not accustomed to guerrilla warfare, had great difficulty defending isolated garrisons, main traffic communications, and major cities. The Third Reich reacted swiftly and on September 16, 1941, the German Supreme High Command issued orders for General Franz Böhme, who was transferred from Greece, to crush the uprising brutally, showing no mercy. He soon undertook full executive and military authority in Serbia. In addition to the three infantry divisions, he had at his disposal an infantry battalion and an anti-tank battalion, which were redeployed from Greece, and the 342nd Infantry Division, which was reassigned from France on

\footnotetext{
${ }^{8}$ B. Petranović, Istorija Jugoslavije 1918-1988. II, 25-51.

${ }^{9}$ Zbornik dokumenata i podataka o narodno-oslobodilačkom ratu jugoslovenskih naroda, tom 1 , knjiga 1 (Beograd: Vojnoistorijski institut Jugoslovenske narodne armije, 1949), 431-432 (further: Zbornik NOR-a I/1); В. Глишић, н. д., 34-35.
} 
September 17, 1941. In the final attack operations, the German units were joined by the 113th Infantry Division, recalled from the Eastern front. ${ }^{10}$

By the beginning of December, General Böhme managed to suppress the uprising and on December 13, 1941, the offensive was officially completed, under the command of General Paul Bader. On December 5, he replaced General Böhme, as the commander general and the military commander in Serbia. That same month, the reprisal formula was 100 people for one killed and 50 for one wounded German soldier. It has been estimated that 7,776 people were killed and shot in combat and 20,149 in retaliation in the period between August of 1941 and February of 1942. ${ }^{11}$

After the uprising had been quelled, a more peaceful period ensued in Serbia. The war crimes of the occupation forces were reduced, but it did not mean that no more atrocities were committed. They were present through the arrest and murder of members of the Royalist and Partisan resistance movements, the deportation of the population to forced labor camps (in Serbia and in the Third Reich), the shooting of civilians in retaliation, etc. Also, concentration camps, such as Banjica ${ }^{12}$ and the Jewish camp in Zemun - Judenlager Semlin (known as the Sajmište concentration camp) ${ }^{13}$ continued to work. After May of 1942, when the Final Solution to the Jewish Question was put into action, this camp received a new, transit function and a new name, the Zemun concentration camp-Anhaltelager Semlin. Atrocities were intensified after September 1942. The German infantry divisions moved to the western parts of Yugoslavia to fight against the Partisan resistance. Bulgarian units and some other special forces took their place, such as the "Prinz Eugen" SS Division. It was redeployed from Banat to Serbia on September 1942 and stayed there until the beginning of 1943 when it was transferred to the west part of Yugoslavia for the same reason as the other German forces. The operations of this division were characterized by numerous war crimes. ${ }^{14}$

${ }^{10}$ Zbornik NOR-a I/1, 440-442, 450-452; Zbornik NOR-a I/2 (Beograd: Vojnoistorijski institut Jugoslovenske narodne armije, 1952), 327; Staniša Brkić, Ime i broj, Kragujevačka tragedija 1941 (Kragujevac: Spomen-park „Kragujevački oktobar“, 2007), 30; В. Глишић, н. д., 55-58.

${ }^{11}$ Zbornik NOR-a I/1, 636-639; Milan Ristović, „Nacistička dominacija u istočnoj i jugoistočnoj Evropi 1939-1945: okupacija, aneksija, saveznički sistem“, Nastava i istorija: časopis prosvetnih radnika, V, br. 7 (2007), 37.

${ }^{12}$ More: Arhiv Jugoslavije (Archives of Yugoslavia, further as: AJ), fond Državna komisija za utvrđivanje zločina okupatora i njihovih pomagača (State Commission in charge of determining the crimes of the occupiers and their abettors), 110-551, inventory number 1827; Sima Begović, Logor Banjica 1941-1944. 1-2 (Beograd: Institut za savremenu istoriju, 1989); B. Глишић, н. д.., 132-143; Evica Micković, Milena Radojčić, prir., Logor Banjica. Logoraši, prvi tom-drugi tom: knjige zatočenika koncentracionog logora Beograd-Banjica (1941-1944) (Beograd: Istorijski arhiv Beograda, 2009).

${ }^{13}$ Christopher R. Browning, "The Final Solution in Serbia-The Semlin Judenlager-A Case Study", Yad Vashem Studies, XV (1983), 55-90; В. Глишић, н. д., 143-151; Milan Koljanin, Nemački logor na Beogradskom sajmištu 1941-1944 (Beograd: Institut za savremenu istoriju, 1992).

${ }^{14}$ More: Valter Manošek, Holokaust u Srbiji. Vojna okupaciona politika i uništavanje Jevreja 1941-1942 (Beograd: Službeni list SRJ, 2007), 157-160; Massimiliano Afiero, The $7^{\text {th }}$ Waffen- 
Over time, the German Army began losing its positions on the war theater worldwide, and its defensive strategy also became evident in Yugoslavia. By the end of December of 1943, the brutal reprisal formula had been abolished. It was difficult to keep track of how many soldiers had been killed, so the mass shootings of hostages after December 1943 became a rarity. ${ }^{15}$

Yugoslavia experienced another wave of atrocities committed by the occupying forces during the struggle for the liberation of the land, which was being waged from the autumn of 1944. The joint action of the Red Army and the Partisan units was followed by numerous massacres. There was a memorable example of Belgrade, where German soldiers, in addition to numerous murders, destroyed and burned down dozens of private and public buildings and cultural institutions without any military justification. ${ }^{16}$

On the other hand, immediately after the liberation of certain towns and villages across Serbia, in the autumn of 1944, the Partisan units, and later the institutions of the newly established Communist authorities, commenced the execution of war criminals who had not escaped as well as ideological opponents - "enemies of the people". The so-called "wild justice" and uncontrolled retribution was mostly carried out from the autumn of 1944 to the spring of 1945, most often in places where the German occupier had carried out executions. It is estimated that more than 60,000 people were killed in this way. ${ }^{17}$

\section{Šumarice - October 1941 - "Villains, you can kill us, but you can never destroy us!"}

The Kragujevac massacre, better known as the "Kragujevac October", deserves a special evaluation of the war crimes committed by Nazi Germany in Yugoslavia. In the fighting around the town of Gornji Milanovac, the partisans and royalists jointly attacked the German 3rd Battalion of the 749th Infantry Regiment of the 717 th Division from Kragujevac. In that battle, the German battalion lost 10 soldiers, with 26 wounded. These losses triggered the worst war crime in Serbia during the occupation.

SS volunteer gebirgs (mountain) division Prinz Eugen (Atglen: Schiffer Publishing, 2016); Srđan Božović, Divizija „Princ Eugen“ (Pančevo: Narodni muzej, 2011), 86-205.

${ }^{15}$ Bojan Dimitrijević, Vojska Nedićeve Srbije. Oružane snage Srpske vlade 1941-1945 (Beograd: Službeni glasnik, 2014), 392-393.

${ }^{16}$ Izveštaj Jugoslovenske Državne komisije..., 25-26; В. Глишић, н. д., 229-230.

${ }^{17}$ More: Kosta Nikolić, Mač revolucije: Ozna u Jugoslaviji: 1944-1946 (Beograd: Službeni glasnik, 2016); Srđan Cvetković, Između srpa i čekića, 1. Likvidacija "narodnih neprijatelja" 1944-1953 (Beograd: Službeni glasnik, 2015); Official site of the State Commission for Secret Graves after September 12, 1944, http://www.komisija1944.mpravde.gov.rs/lt/ (accessed August 20, 2018). About liquidation in other countries see for exemple: Dimitris Kusouris, "From Revolution to Restoration. Transnational Implications of the Greek Purge of Wartime Collaborators", Dealing with Wars and Dictatorships (2014), https://www.academia.edu/5901648/ From_Revolution_to_Restoration_Transnational_Implications_of the_Greek_Purge_of_Warti me_Collaborators_2014 (accessed August 20, 2018); Jelena Lilić, "Comparison between Serbia, Greece and Bulgaria - Trials of Collaborators 1944-1948" (masterwork, Hugo Valentine Center, Upsala University, 2013). 
Immediately after the return of the German battalion to Kragujevac on October 18, 1941, they began arresting the population that was to be shot in retaliation. This campaign of rounding up and shooting of civilians in Kragujevac was conducted by the 3rd Battalion of the 749th Infantry Regiment of the 717th Division under the command of Captain Fritz Fidler and the 1st Battalion of the 724th Infantry Regiment of the 704th Reserve Division under the command of Major Paul König. Together with the battalions of the regular army, all other German institutions in the city were active in this bloodbath: the Secret Military Police (GFP) led by Commissioner Rudolf Berg, the Military Gendarmerie Detachment, led by First Lieutenant Franz Hazel, the Industrial Protection Detachment"Werkschutz", the Military auto-base NKR-533, the Volksdeutsche organization, the semi-military organization "Deutche Manschaft" and the collaborationist formation-5th Volunteer Detachment of Marisav Petrović. As the number of hostages to be shot was 2,300, on the recommendation of the Kreiskommandant Captain Otto von Bischofshausen, arrests, burnings of homes and shootings were carried out in the surrounding villages (Grošnica, Mečkovac, Maršić), on October 19, 1941. The number of casualties at that moment was not even close to the final number, so the arrests continued in Kragujevac on October 20. Workers, priests, men and women in churches, as well as students from Kragujevac high schools, were arrested. The executions began on the evening of October 20, and mass shooting early in the morning of October 21, 1941. In this way, between October 19 and 21 , over 2,790 persons were shot dead. ${ }^{18}$

Information about the number of killed is different and varies between 2,300, according to Nazi sources, and 12,000. There is a prevalent opinion that the number of people killed was 7,000. It is the number accepted in Yugoslav historiography for several decades after the end of World War II. The " 21 st October" Memorial Museum has collected personal information on 2,796 casualties and personal information on 61 persons who survived in the period from October 19 to October 21, 1941. ${ }^{19}$

The "21st October" Memorial Museum, which is located in the "Kragujevac October" Memorial Park, carefully preserves the memory of this event. Also, numerous literary works that came out in the past decades contain many testimonies, photos and memories of this tragic event. In this text we will highlight the most characteristic testimonies in order to better analyze our work.

Early in the morning, before the shootings, during the aligning and separation carried out by the German soldiers, there were several unrepeatable

${ }^{18}$ Izveštaj Jugoslovenske Državne komisije..., 19-20; Zbornik NOR-a I/1, 548-553; S. Brkić, n. d., 47-74; Staniša Brkić, Nenad Đorđević, Grosse Vebrechen der Wehrmacht, Kragujevac 1941 (Kragujevac: S. Brkić, 2004); В. Глишић, н. д., 65-67; V. Manošek, n. d., 160-164; Official site of The Memorial Park "October in Kragujevac", https://www.spomenpark.rs/rs/ (accessed August 22, 2018).

${ }^{19}$ More: S. Brkić, n. d.; Official site of The Memorial Park "October in Kragujevac", https:// www.spomenpark.rs/rs/ (accessed August 22, 2018). 
scenes of human courage and honesty. From a group that had to go toward $\breve{S u-}$ marice, Miodrag Novaković, a teacher in the Kragujevac High School, called to the group in the field that stood in front of the German rifles: "Goodbye brothers, be brave, because of these bastards! If one of you survives, be damned if he does not revenge us!" One of the German soldiers waved a gunstock, with the intention of hitting him. Miodrag turned to him and said: "What do you want from me, you Hun bastard? Is my death not enough for you?"20

One of the hostages, Lazar Pantelić, principal of the Second Male High School in Kragujevac, was lucky for a moment. A German looked at his documents and found that he was important for the community. He was taken out of the group. Standing in line with those who had been spared, he watched the Nazis arranging the following groups. In one of these groups he saw many of his students. He came to a German officer and asked him: "Where are you taking these children? I'm their principal. Please let them go, and take me!" "It cannot be done", was the response. "Then my place is not here. My place is with my students!" He went to death with his students, leaving five of his children at home. ${ }^{21}$

There was also a witness of the shootings in Šumarice. Vojislav Zorić, the guardian of the Comić's villa and worker on the estate, who, hidden, watched the entire event from the immediate vicinity: "Conductors still did not move away even a hundred meters, and a new group of people already stood at the entrance of the orchard. But they did not want to wait calmly: they were spreading all over [...] one jumped over a fairly high fence and continued the escape toward the Wild Field. But he also fell, shot. One worker hid himself between cornstalks and they found him there later, but in a state of despair and with foam on his mouth. Some ran across the road and there they were mowed down. Four of them, across the ravine and up the road, saved their heads". ${ }^{22}$

The last thoughts of those who went to the shooting were addressed to their loved ones. The Germans were taking away their documents and other personal items and therefore, they were now saying goodbye in their minds to their wives, children, mothers, fathers, girls, etc. There were few of those who found a piece of paper and a pen, and they wrote their last words at those moments. In the documentation of the Museum "21st October" there are 42 messages, but they can freely be considered as messages of all who were shot. Short and concise, they represented all the pain and agony that the victims endured: "Don't send me any bread tomorrow, Jakov", "My dear dad and mom, my last regards, Ljubiša", "Goodbye my dearest. Killed innocent. Yours forever, Andra", etc. ${ }^{23}$

Immediately after the shooting, which lasted continuously for seven hours, the municipal authorities formed burial teams. About two hundred people

\footnotetext{
${ }^{20}$ S. Brkić, $n$. d., 60-61.

${ }^{21} \mathrm{Ibid}$., 61-62. According to the informations from the Memorial Museum "21st October", a total of 40 children of Serbian and Roma ethnicity aged 11 to 15 years old were shot. The Nazis also killed 261 young men, primarily high school students from Kragujevac.

${ }^{22}$ Dragoljub Petrović, Preživeli optužuju (Kragujevac: Spomen park, 1966), 142.

${ }^{23}$ S. Brkić, n. d., 65-68, 106-128.
} 
were burying the victims over a period of several days. On the way to the killing fields, not knowing what to expect, after all that they experienced the previous day, many were scared. An old conductor calmed them down: "Do not be afraid! You know how it is. The city is threatened by the infection. Many people were killed and there is no one to bury them". ${ }^{24}$

However, the German reports were dominated by an aloof attitude. The main executor of the retaliation, Major König, informed the Headquarters of the 704th Infantry Division: “[...] 21. X'41 at 7:00 in the morning begins the selection and the shooting of the hostages. Thereby action ended; a total of 2,300 Serbs of different ages and calls were shot. The next days in the population, for understandable reasons, a great deal of excitement was observed. Security measures are being taken". ${ }^{25}$

Without any compassion, in a more comprehensive report, Kreiskommandant Captain von Bischofshausen pointed out that the shooting had to be carried out in the area where the German soldiers had been attacked, primarily for tactical reasons: "[...] Shooting a part of completely innocent people from this city can have, according to my conviction, dire consequences. It can be expected that the indignant relatives of those who were killed will take revenge on the members of the German Armed Forces [...]"26

Even during the war itself, the massacre of innocent civilians in Kragujevac on October 19-21 1941, received an aura of martyrdom and carried the epithet of one of the most tragic events in World War II on the territory of Yugoslavia, mostly because of the shooting of children and students, and the fact that a huge number of innocent people were killed in a very short time. All the relevant wartime factors in Serbia reacted to this atrocity from their own angles. The Yugoslav government-in-exile also reacted. The participants of such a commemorative event were the students of the "Ginazio Piedade" High School in Rio de Janeiro. They held a holy service at the Church of St. Francis of Paola on December 30, 1941 for the murdered students and their professors. ${ }^{27}$ On October 22, 1942, King Peter II awarded Kragujevac with the Order of the Star of Karadjordje With Swords, and in London on November 25, 1942, a solemn allied commemoration was held for the victims of the Kragujevac massacre. ${ }^{28}$ After the end of the war, in its Report to the International Military Tribunal (IMT) in Nuremberg, the Yugoslav State Commission in charge of determining war crimes by the occupation forces and their accomplices, submitted evidence

${ }^{24}$ D. Petrović, $n$. d., 169.

${ }^{25}$ Zbornik NOR-a I/1, 580.

${ }^{26}$ Ibid., 553.

${ }^{27}$ AJ, fond Vlada Kraljevine Jugoslavije u izgnanstvu (Government in exile of the Kingdom of Yugoslavia), 103-24-162; AJ, fond Poslanstvo Kraljevine Jugoslavije u Argentini - Buenos Aires (Legation of the Kingdom of Yugoslavia in Argentina - Buenos Aires), 385-9-54; S. Brkić, n. d., 7-8.

${ }^{28}$ S. Brkić, n. d., 8. 
of the massacre in Kragujevac and in that way informed the world about this tragic event. ${ }^{29}$ The new communist government attached great significance to this event and that could be seen from the fact that the head of state, Josip Broz Tito, visited Šumarice four times during his lifetime, whereas, for example, he never visited the place where the Ustasha camp Jasenovac was located. ${ }^{30}$

Memorializing the victims was raised to a higher level when the "Kragujevac October" Memorial Park was founded in 1953 at the site of the massacre. The tasks of the Memorial Park were the construction and arrangement of the memorial space. A path around the park was made, along with hiking trails, and 12 monuments were built in the meantime. The most famous sculpture in the memorial area is the "Monument to the Murdered Students and Teachers", the work of sculptor Miodrag Živković, installed in 1963. It was built on the place where the soldiers shot the biggest group of students and 15 teachers. The monument soon became the symbol of the city of Kragujevac, and events are held there on October 21 of every year. With the funding of the citizens of Kragujevac and the government, the "21st October" Memorial Museum located in the Memorial Park, was built and opened in 1976. The main tasks of the museum are researching and collecting of materials about the shooting and about those who were killed; additional tasks include educational work, nurturing and keeping alive the memory of the victims by organizing various events. So far, more than 5 million visitors have passed through the museum. ${ }^{31}$

Immediately after the massacre on October 21, 1941, the German Command in Kragujevac put up a poster in several places informing people that, because of "a cowardly and insidious attack last week in which 10 German soldiers were killed and 26 wounded", 2,300 persons had been shot "primarily communists, bandits, and their abettors". However, even during the occupation, it was assumed that many more people had been shot. Soon, the myth of 7,000 murdered hostages was spread after the liberation of Yugoslavia. The myth was also adopted and supported by the communist government. Later on, historian Venceslav Glišic ${ }^{32}$ and several other historians opposed this myth. After the death of Josip Broz Tito in 1980, the ideological "restrictions" in society were reduced and the past was re-examined, which required more expert analysis. A text appeared in the press in the early 1990s, with information made available from the "21st October Museum", but the public reaction was furious. The convicts came from all sides. It was written about history being desecrated and that this "crime" was hardly measurable to the crime committed by the occupational forces. ${ }^{33}$

${ }^{29}$ Boris Tomanić, „Kragujevački oktobar na Nirnberškom procesu“, Godišnjak za istraživanje genocida, 8 (2016), 245-250.

${ }^{30} \mathrm{~S}$. Brkić, n. d., 8.

${ }^{31}$ S. Brkić, $n$. d., 8-9; "Spomenici u memorijalnom prostoru", Official site of The Memorial Park "October in Kragujevac", https://www.spomenpark.rs/rs/spomenici-u-memorijalnom-prostoru (accessed August 22, 2018).

${ }^{32}$ See: V. Glišić, n. d., 65-67.

${ }^{33}$ S. Brkić, n. d., 91-93. 
Ideological and political constraints were certainly the main cause of the bad attitude toward this topic, but the fact is that the myth of 7,000 killed has survived to this day. Therefore, the questions arise whether the only constraints are ideological and political and where the limits are of our acceptance or rejection of these restrictions.

\section{Metino Brdo - March 1942, January 1944, 1944/1945 - "Neighbor, tell my dearest where I got killed!"}

During the period when Otto von Bischofshausen was Kreiskommandant in Kragujevac, Metino Brdo Camp was created in the warehouses of the Military Technical Institute. The first prisoners began to arrive in November of 1941, mainly from the Šmadija region, primarily from the greater Kragujevac area. The Metino Brdo Camp primarily had a transit function, although, there were frequent arrivals of prisoners to the camp, who would later serve as hostages the retaliation shootings. They were beaten and tortured. Some of them were shot, while others were sent to the Bor mines in Serbia or to Germany and Norway, where many died of excessive labor, hunger and diseases. ${ }^{34}$ Others were forced to move from camp to camp with constant torture. Only a small number of inmates were sent homes after several months spent in prison camp. This situation lasted until June of 1942, when the camp was disbanded. This crime was conducted with generous assistance from the presidents of municipalities, chiefs of villages, members of municipal administrations, and military units of the Serbian Government of National Salvation (Government of Milan Nedić), etc. ${ }^{35}$

In the camp, there were three barracks with two watchtowers, an outpatient clinic and a guardhouse. The first hostages in the camp were the prisoners from Kragujevac, political workers, sympathizers and fighters of the Partisan resistance, Roma, Jews and all those who were suspicious to the Nazi German authorities. The prisoners were separated into groups designated for shooting, transport to the Banjica and Sajmište camps and to the female quarters. ${ }^{36}$

In addition to the constant executions of smaller groups of people, which began on February 13, 1942, two larger massacres were recorded on March 2, 1942, on Metino Brdo, and on March 22, 1942, in Medna, in the vil-

\footnotetext{
${ }^{34}$ More: Živko Avramovski, Treći Rajh i Borski rudnik (Bor: Muzej rudarstva i metalurgije „Bor“, 1975); Љубомир Зечевић и Тамара Ћирић, Концентрациони логор Маутхаузен повратак непожељан (Београд: Удружење заточеника КЛ Маутхаузен Србије, 2015); М. Koljanin, $n$. d.; Ljubo Mlađenović, Pod šifrom Viking: život, borba i stradanje jugoslovenskih interniraca u logorima u Norveškoj 1942-1945 (Beograd: Institut za savremenu istoriju 1991); Tomislav Pajić, Prinudni rad i otpor u logorima Borskog rudnika 1941-1944 (Beograd: Institut za savremenu istoriju, 1989).

${ }^{35}$ AJ, 110-95-295-310; AJ, 110-393-6, Decision for von Bischofhausen number: 1815, file number: 3664 .

36 Željko Zirojević, Mart 1942. g. Streljanje antifašista. Metino brdo-Medna (Kragujevac: SUBNOR, 2012), 23.
} 
lage of Donja Sabanta, near Kragujevac. ${ }^{37}$ Over 250 people were killed in these two massacres, and only a few managed to escape. The last shooting on Metino Brdo during the occupation was recorded on January 20, 1944, nearly two years after the camp had been disbanded. ${ }^{38}$

The State Commission in charge of determining the crimes of the occupation forces and their abettors, which operated from 1943 to 1948, collected 244 reports concerning the Metino Brdo Camp. There were 61 reports on the shooting in the Metino Brdo Camp on March 2, 1942, three on the shooting in the Metino Brdo Camp on March 7, 1942, 98 reports on the shooting on March 22, 1942, in Medna, 71 reports on the persons who passed through the Metino Brdo Camp, and 13 reports on the shooting in the Metino Brdo Camp on January 20,1944 . In addition to the testimonies of the families and relatives of the victims, the Commission managed to take statements from survivors. ${ }^{39}$ Also, the survivors gave their testimonies during World War II in front of the Special Police Department. For example, Mihajlo Simović, a farmer from the village of Vukosavci, managed to escape the shooting on Metino Brdo on March 2, 1942, but he was captured at the beginning of June 1943 and after a hearing at the City Police Station in Kragujevac, he was taken away and shot in Kapislana. ${ }^{40}$

On February 13, 1945, one of the survivors, Branislav Stevanović, a farmer from the village of Brezovac, told the State Commission of the Committee of Orašac how he survived the massacre. When the Germans started shooting in Metino Brdo, Branislav Stevanović escaped and managed to reach Kragujevac, but he was wounded in his right hand and left leg. He hid in the basement of a house in Kragujevac, but the man of the house found him and started to beat him with a shovel, asking his wife to bring him an axe to cut off his head. He escaped and took cover in another house. The owners found him, but unlike the previous owners, they gave him some bread. In the evening he headed for Brezovac, but he did not get far. After nine days, he collapsed in the village of Trnava from the

\footnotetext{
${ }^{37}$ In the reports collected by the State Commission in charge of determining the crimes of the occupiers and their abettors, various dates appear related to the shooting in Medna. Although the date March 20 dominates, March 8, 15, 17, 18, 21 and March 29 are also mentioned. According to the website of SUBNOR Serbia and the book of Željko Zirojević, the shooting took place on March 22, although some websites say that shootings took place on March 19. Since SUBNOR Serbia is the organization which mainly takes care of remembering victims, in the main part of the text we have given a date on March 22, 1942. AJ, 110-393-165-393-441; Z̆. Zirojević, $n$. d., 33-34, 43; „Polaganje venaca na Metinom brdu“, Official Site of Tourist organization of Kragujevac, http://gtokg.org.rs/srb/polaganje-venaca-na-metinom-brdu/ (accessed August 22, 2018); „Medna-Rodoljubi nikada neće biti zaboravljeni“, Official site of SUBNOR Serbia, http://www.subnor.org.rs/medna-4 (accessed September 1, 2018).

${ }^{38}$ AJ, 110-95-295; AJ, 110-95-310; AJ, 110-393-6, f. br. 1815, dos. br. 3664.

${ }^{39}$ AJ, 110-393-1; AJ, 110-393-730, dos. br. 3664.

${ }^{40}$ Istorijski arhiv Beograda (Historical Archives of Belgrade), fond Uprava grada Beograda, Specijalna policija (Administration of the city of Belgrade, Special police department), box: 429, article: IV-Q-189/69 (further: IAB, UGB, SP).
} 
pain and profuse bleeding. He was found by the local militia and handed over to the German garrison in the town of Topola. He was rescued from the prison in Topola on the evening of the same day by a group of partisans who took him away from there and concealed him in a hayrack in an adjacent village, telling him they would come for him the next night. But he was caught again and returned to the prison in Topola. Soon he was transferred to Belgrade and kept at the Orthopedic Department because his life was in danger. He had two operations and after five months, at the recommendation of the German Command, he was released home. His left leg and his right hand remained disabled. ${ }^{41}$

Another survivor Dragoljub Savić, a tailor from the village of Vrbica, described his escape to the State Commission of the Committee of Orašac municipality on March 28, 1945. At about five thirty in the morning, around 160 persons had been taken out of the Metino Brdo Camp. About one kilometer away there was a ditch, where they were supposed to be buried. Those who did not want to go into the ditch were stabbed with bayonets. When everyone had gone down into the ditch, the soldiers opened fire. Dragoljub Savić was wounded in the leg. The bullet went through his calf muscle and came out at the heel. At that moment, he noticed two people running in front of him. He took off his short winter coat and threw it on the head of a German soldier. In this way, he managed to crawl out of the pit and escape, although two more bullets hit him in the legs. After a few days, he was caught in the Ramaća village and taken to the village of Stragari. From there, together with Branislav Stevanović from Brezovac, he was handed over to the Germans in Topola. After several days he was taken to Aranđelovac, and after a while he was released. ${ }^{42}$

The agony of the victims during the shooting and the sadism of the German soldiers were constantly present. Milan Ivanović from Kragujevac spoke about this, in his testimony to the State Commission of the Committee of the City of Kragujevac on February 16, 1945. He survived the massacre in Sumarice by escaping to the town of Svilajnac on October 18, 1941. He returned to Kragujevac on October 24, seeking a job and found it in the municipality, in a labor battalion. After a few months, about 40 workers from this battalion were sent to the Military Technical Institute where the Germans boarded them on a train to the Metino Brdo Camp. In the same train he saw prisoners already prepared for execution. When the train arrived in Medna, the Germans unloaded a group of 50-60 prisoners whose hands had been tied behind their backs and took them 300 or 400 meters from there, to a large ditch, which was about 10 meters long, 5 meters wide, and 2 meters deep. Beside the ditch, there was another group of 50-60 prisoners who had been transferred a little earlier. The surroundings were blocked by Bulgarian soldiers. The victims were brought into the ditch in groups of 10 to 15 , and about 40 Germans opened fire from a distance of 20 meters. The execution, according to Milan Ivanović, was carried out in the following manner: "During the shooting, a German officer was standing on the edge of the ditch. As soon as a

\footnotetext{
${ }^{41}$ AJ, 110-393-148; AJ, 110-393-149, dos. br. 3664.

42 AJ, 110-393-152; AJ, 110-393-667, dos. br. 3664.
} 
group of 10 to 15 people were killed, three Bulgarian officers, who were standing a couple of steps back during the shooting, immediately approached to establish the death of the prisoners. If anyone was giving signs of life, they would show them to the Germans and two fat German soldiers with glasses would come running to finish them off with revolvers by firing at their necks. These two soldiers were racing who would finish the victim off first. So when, at one point, one of them had a bullet stuck in his pistol, he pulled the gun from the hand of the other German and killed a man". 43

During the shooting, the last words were coming out from the mouths of the victims: "Goodbye friends", or "Neighbor, tell my dearest where I got killed!" but also defiant shouts: "Hit it, you bastards, you will have your Black Friday!" 44 The workers who were brought in stacked the dead in groups like cordwood and finally buried them in the ditch. ${ }^{45}$

Milan Ivanović also witnessed a shooting at Metino Brdo, which happened several weeks earlier. The workers also had to collect the corpses in the surroundings of the excavated ditch, because during the execution many people had tried to escape. There were corpses scattered throughout the entire area, all the way to a place called Teferič and the Bresnica River, within a radius of about 2 kilometers, which the workers carried on their backs or loaded onto carts and stacked in the ditch. In total, 77 bodies were transferred in such a way. When the corpses were buried, the local militia brought four peasants who had tried to escape from the shooting and the German soldiers immediately killed them too. ${ }^{46}$

After the liberation of Kragujevac on October 21, 1944, the Communist authorities began to liquidate their ideological enemies. At the wartime site of Metino Brdo, in the autumn of 1944, the new authorities re-established a camp with three camp units: for the German prisoners of war, for Serbian men, and for Serbian women. In addition to the fence on the outside, there was an inside barbed wire fence between these three units. ${ }^{47}$

The priest Miodrag Jelic from the town of Velika Plana testified to the tragedy that took place in the male prison camp: "From the prison of the court, I was transferred to Metino Brdo. I spent several months there, doing the hardest physical tasks. Every morning, before taking us out to work, they pulled someone out of the ranks and shot him. They asked for peace, discipline, and work, telling us that this was the only way we could prove our patriotism and our readiness to help restore our demolished homeland. And, for example, every morning, one of us was taken out of the line and shot. If there was no other guilt, the commander of the camp yelled: What are you talking about there? Get

\footnotetext{
${ }^{43}$ AJ, 110-393-665, dos. br. 3664.

${ }^{44}$ A Serbian curse that approximately means: You will have your Judgment Day.

${ }^{45}$ AJ, 110-393-665, dos. br. 3664. See also: AJ, 110-393-675; AJ, 110-393-676, dos br. 3664.

${ }^{46}$ AJ, 110-393-665; AJ, 110-393-666, dos. br. 3664. See also: AJ, 110-393-678; AJ, 110-393679. dos. br. 3664.

${ }^{47}$ Slobodan Ćirović, Na tragu zločina. Gruža u četnicima II, 1944-1952 (Kragujevac: Nova svetlost, 2003), 236.
} 
out! And the guards pulled out the chosen unfortunate man. It was the way to freedom that they brought to us $[\ldots]^{\text {"48 }}$

$$
* * *
$$

After the end of World War II, there was not much attention dedicated to the events that took place on and around Metino Brdo, because the number of victims was significantly lower compared to Šmarice and, on the other hand, because of the fact that killings were also carried out by the communist authorities in the same place. In 1981, a statue was built at the Medna killing field. Later, in 1987, on Metino Brdo, at the place where on March 2, 1942, one of the victims threw a coat on a German soldier and managed to save several people, the monument called "Hostage" was built, the work of sculptor Dragan Panić. Also, in 2012, a book was published about the shootings on Metino Brdo and Medna. Today, only the veteran organization SUBNOR, a Serbian Army delegation, and the representatives of the city of Kragujevac, pay tribute each year to the victims shot during the occupation. 49

However, the State Commission for secret graves of persons killed after September 12, 1944, (founded in 2009), whose aim was to investigate, locate, and mark all the secret graves of those who had been shot after September 1944, recorded that there was indeed a killing filed on Metino Brdo. Unfortunately, this location has not been examined in detail, so the authorities have a duty to explore the location, probe the ground, and carry out exhumations. ${ }^{50}$

Historiography still has not finally answered many questions: Was Metino Brdo a camp in a real sense? When and how did the shootings happen exactly? How many people were killed after the liberation in 1944 and in what way? etc. Collective memorization will not take its definitive form until all these questions have been answered.

\section{Kapislana - winter of 1942-winter of 1943, 1944/1945 - No voice from Kapislana}

One of the means of mass destruction of the Yugoslav population, which was applied extensively by the Wehrmacht and the Government of the Third Reich, consisted of arresting and killing hostages. Also, the Nazi authorities gave publicity to the shooting of hostages through "announcements"

\footnotetext{
${ }^{48}$ S. Ćirović, Na tragu zločina, 278-280; Slobodan Ćirović, Razgovori u porti pod zapisom (Kragujevac: Nova svetlost, 1995), 333; „Logor na Metinom brdu u Kragujevcu“, iKragujevac, http://www.ikragujevac.com/vesti/24241-logor-na-metinom-brdu-u-kragujevcu.html (accessed August 24, 2018).

49 Ž. Zirojević, $n$. d., 85-88; „Polaganje venaca na Metinom brdu“, Official Site of Tourist organization of Kragujevac, http://gtokg.org.rs/srb/polaganje-venaca-na-metinom-brdu/ (accessed August 24, 2018).

${ }^{50}$ Srđan Cvetković, Komisija za tajne grobnice ubijenih posle 12. septembra 1944. Godišnji izveštaj 2010 (Beograd: Državna komisija za tajne grobnice ubijenih posle 12. septembra 1944, Institut za savremenu istoriju, 2010), 19, 37-38.
} 
printed in the form of posters whenever this was necessary for the intimidation of the population.

The shooting and execution of the population of Kragujevac and the surrounding area was carried out mostly in the Military Technical Institute, at a place called Kapislana, and on Metino Brdo. The best descriptions of these massacres were given after the war by the workers of the Military Technical Institute and the Technical Section in their testimonies to the State Commission in charge of determining the crimes of the occupation forces and their abettors during 1945, and the State Commission of the Committee of the city of Kragujevac and the State Commission of the Committee of the County of Kragujevac, respectively. According to the order of the Kreis-Kommandatur in Kragujevac, they had to dig the ditches and bury the victims who were shot in retaliation from time to time. ${ }^{51}$

The author managed to find 17 posters that were signed by the FeldKommandantur in the town of Vrnjačka Banja. They show clearly that in the period between November 2, 1942 and October 17, 1943, the number of people killed in this way was 318 . However, the actual number is much higher if we know that only a relatively small number of posters were confiscated and that the Germans published only some of the shootings.

From the statements collected by the aforementioned commission, it is clearly evident that the shootings were carried out by the local German police, while the SD (SS Security Service) suggested who should be shot. ${ }^{52}$ It seems that the Industrial Protection Detachment-"Werkschutz" was also involved in the shootings. The "Werkschutz" was composed mainly of the Volksdeutsche from Banat. The commissioner of the Military Technical Institute, Rothe visited the Institute almost every day and held guard posts. The main functions of the "Werkschutz" were to take care of the safety of the Institute, provide guard posts, and search the workers when they were leaving the Institute. ${ }^{53}$ The entire prison where the hostages were kept was under the control of the "FeldGendarmerie" whose commander was Karl Urban. ${ }^{54}$

The German soldiers carried out the shootings systematically and brutally. This was confirmed by Mirko Brojčin, a fireman from the town of Iđoš, in his testimony to the State Commission of the Committee of the city of Kragujevac on March 16, 1945. According to him, the shootings were carried out in the following way: "[...] SD makes a list of the persons for the shooting and delivers that list to the Feld-Gendarmerie, and from the Feld-Gendarmerie, the Feldwebel comes with two or three gendarmes and, according to the list, calls and separates [the hostages] into a separate room-room number 20. This separation was carried out

\footnotetext{
${ }^{51}$ AJ, 110-475-743; AJ, 110-475-756, dos. br. 4331.

${ }^{52}$ AJ, 110-475-750; AJ, 110-475-751, dos. br. 4331.

${ }^{53}$ AJ, 110-393-29; AJ, 110-393-31, dos. br. 3664.

${ }^{54}$ AJ, 110-475-750, dos. br. 4331.
} 
usually in the morning and the detainees stayed up until five o'clock in the afternoon, when they were shot. These shootings were always attended by [Karl] Urban, and on one occasion by four to five Bulgarian officers [...] I note that the shootings were carried out once a week and the number of those killed was never the same. I can say that about 20 people were shot on a weekly basis. These shootings were carried out in Kapislana and on Metino Brdo, and [victims] were buried by municipal workers. These municipal workers took back the suits of those who had been shot because the victims were first undressed and then shot. These suits were kept in a warehouse, and when a lot of clothes were amassed, the municipal car would come and drive those things away, I do not know where". 55

Stevan Kolaković, a worker from the town of Grocka, participated in the burial on February 15, 1943, but also in digging ditches and burying other victims who were shot later in 1943. These events remained stamped in his memory. In a statement given to the State Commission of the Committee of the city of Kragujevac on March 24, 1945, he said, among other things: ,When we arrived there, as I found out later, the victims shot on February 15 were buried, and we were ordered to fill up the ditch with some more soil and level it. After a while, we were sent again by the Technical section to work at the Institute in Kapislana, and we dug there, as I remember, one ditch 8 x 8 meters long and 1, 90 meters deep. In the pit, we had to make stairs on one side, so they could get down. After a few days we were again summoned by the Germans and we would come to the main entrance of the Institute and wait there. Usually a German soldier on a bicycle would come and order us to run in front of him [...] all the way to Kapislana. When we got to the ditch, we found killed people in it, someone's head was blown up, someone's body was scattered, and the corpses were usually shot. The corpses were in pants and shirts, barefooted, without hats, and their clothes and shoes stood on one pile near the ditch. Then, the Germans ordered 6 workers to jump immediately into the pit and to sort them [the victims] like sardines [...] When we finished sorting the corpses, The Germans ordered us to get out of the pit and fill it up with a half a meter of soil $[\ldots]^{\text {“56 }}$

After the liberation of Kragujevac, Kapislana remained a place of suffering. In it, the new Communist Government was liquidating ideological enemies. According to Miodrag Beljaković, who was a student of the Kragujevac High School after the liberation, "only the well-known prisoners, against which there was plenty of evidentiary material, were taken to trial", while the others were shot after a summary procedure, without any investigation, and declared guilty. The liquidation of "enemies of the people" was carried out almost automatically at precisely determined times. Regarding this, M. Beljaković said: "We were listening to the rumbling of the machine guns early almost every morning, between two and four o'clock, for months. I was already used to it and at that time, with a creepy feeling, I was automatically awaked". ${ }^{57}$ Even the

\footnotetext{
${ }^{55}$ AJ, 110-475-750; AJ, 110-475-751, dos. br. 4331.

${ }^{56}$ AJ, 110-475-743, dos. br. 4331.

${ }^{57}$ Miodrag Beljaković, Pod oblacima Srbije (Kragujevac: Jefimija, 2004), 198-201.
} 
County Court building was not sufficient for the numerous trials that were held after the liberation. Because of this, some processes were conducted in the High School hall or the large hall of Nikolajević's house in Kragujevac. ${ }^{58}$

Vladislav Sretenović, a former officer of the OZN-a, ${ }^{59}$ testified in 2011 in the daily newspapers "Blic" about the liquidations in Kragujevac:

"First we made arrests in the villages, and then in the city, of all of those who had been marked as traitors. All of them, according to the decision of the court, were shot. Most of them were killed in Kapislana, and those were the basements which you photographed. They were brought there because they could not escape, and the inhabitants could not heard the shots. It was a difficult time, and those who were not guilty were also killed there $[\ldots]^{\prime \prime 60}$

$$
* * *
$$

Just like on Metino Brdo, the Communist authorities used this infamous killing site for the liquidation of their ideological enemies. It is exactly why a long struggle was led over the setting up of a mark that would suggest that shootings were carried out there. Only just at the beginning of the 21 st century, details about the crimes after World War II that happened in Kapislana started to be revealed. Leading Serbian newspapers "Večernje novosti" and "Politika", as well as the national public service "Radio Television of Serbia", in the period 2009-2011, frequently reported to the public about these crimes. The victims were killed and mostly buried at the place where the ,Zastava“" car factory was later built, some of the tombs had been discovered earlier, but many of them have still not been found. It is not known how many people were shot; the numbers are between 800 and 2,000. The descendants of the victims were never allowed to mark or at least light candles at the place where their ancestors had been shot. ${ }^{61}$

According to the data from the monograph of historian Srđan Cvetković, during the installation of the rails in the circle of the „Zastava" factory around 1955, workers dug up shallow mass graves with buried corpses. Another mass grave with about 400 corpses in "Zastava" was discovered when the new building in the factory complex was built on the site of the former Kapislana. However, the victims of the new authorities cannot be clearly distinguished from the victims that the Germans shot in Kragujevac during the occupation. ${ }^{62}$ In the 1970 s, it was decided that the mortal remains of 46 or 47 Partisan fighters and sympathizers

\footnotetext{
${ }^{58}$ Ibid.

${ }^{59}$ The Department for People's Protection or OZN-a was the security agency of Yugoslavia that existed between 1944 and 1946.

${ }^{60}$ „Priznanje oficira Ozne: U Kapislani su streljani i nedužni“, Blic, August 17, 2011, https:// www.blic.rs/vesti/reportaza/priznanje-oficira-ozne-u-kapislani-su-streljani-i-neduzni/2mmyzrn (accessed September 1, 2018).

${ }^{61}$ „Kragujevac: Grobnica ispod parkinga?“ Večernje novosti, December 9, 2011, http://www. novosti.rs/vesti/srbija.73.html:357029-Kragujevac-Grobnica-ispod-parkinga (accessed September 1, 2018).

${ }^{62}$ Srđan Cvetković, Između srpa i čekića. Represija u Srbiji 1944-1953 (Beograd: Institut za savremenu istoriju, 2006), 224, 226.
} 
killed during 1943 should be transferred to the City Cemetery in Kragujevac, on parcel number 9. Soon there was also a memorial plaque. Shortly thereafter, at the beginning of the 1980s, hundreds of mortal remains of people killed after the liberation by the new government were transferred and also buried on parcel number 9 , but without any grave markers. ${ }^{63}$

At the end of the 1990s, an initiative was made to set up a commemorative tablet for the victims of the Communist terror. On October 1999, the city authorities, under the democratic coalition, decided to set up a monument not far from the killing site, outside the "Zastava" factory circle. However, the central government authorities, at that time led by the political successors of the Communist Party of Yugoslavia, issued an order that this should not be allowed. Police cordons prevented the attempt, by the city authorities and the descendants of the victims, to set up the monument and for the first time hold church services for the victims. There was a conflict with the police and almost new bloodshed between the "communists and anticommunists". On the monument that was built after the democratic changes in 2000, is the inscription: "To the citizens of Kragujevac and the surrounding towns, who succumbed to the Communist terror in 1944". Also, there is a date: "October 21, 1999". ${ }^{64}$

There is also an idea to place a common memorial on parcel number 9 in memory of all the victims of the shootings during and after World War II. The descendants of the victims of the post-war communist purge, however, do not approve of this intention of the city authorities. Petar Simović, the son of Dragomir Simović, trader and pre-war Mayor of Kragujevac, who was killed after the war, thinks that such an idea is unacceptable. He says that "innocent victims cannot be the same as killers". ${ }^{65}$

It is necessary to take many more steps, to make more expert analyses, to submit a more complex comparison of the events during and after World War II, in order to finally formulate a public opinion about the crimes in Kapislana. For now, this killing site remains one of the most intriguing parts of contemporary Serbian history.

63 “Pucalo kao da su se Nemci vratili!", Večernje novosti, June 17, 2009, http://www. novosti.rs/vesti/naslovna/aktuelno.69.html:242821-Pucalo-kao-da-su-se-Nemci-vratili (accessed September 1, 2018); “Tajna parcele broj 9,“ Politika, August 18, 2010, http://www. politika.rs/sr/clanak/146415/Tajna-parcele-broj-9 (accessed September 1, 2018).

64 "Pucalo kao da su se Nemci vratili!", Večernje novosti, June 17, 2009, http://www. novosti.rs/vesti/naslovna/aktuelno.69.html:242821-Pucalo-kao-da-su-se-Nemci-vratili (accessed September 1, 2018).

65 “Tajna parcele broj 9," Politika, August 18, 2010, http://www.politika.rs/sr/clanak/146415/ Tajna-parcele-broj-9 (accessed September 1, 2018). 


\section{Conclusion}

The horrors that happened in Kragujevac represent a complex structure of crimes in which many components are noticed. The first and most visible is the chronological component in which the crimes are clearly divided into those that occurred during World War II and after the liberation of Serbia. There is also an ideological component: the German invaders carried out executions of captured antifascist fighters, while civilians were killed in retaliation as hostages; on the other hand, in the executions carried out by the new communist government, only the ideological element is evident. During World War II, peasants and farmers suffered the most, while in the communist "wild justice" purges many people from the upper-class civic community were killed. Thus, this part clearly identifies the social component.

Continuity in crimes is also clear. They were carried out, to a greater or lesser extent, during the entire war, and continued, with the same violence after the liberation of the land, most often in the same locations. Metino Brdo and Kapislana stand out as clear examples, which is why it is very difficult to determine the boundaries of the communist crimes and the German crimes at these sites.

A collective perspective on the crimes committed in Kragujevac was twofold and uneven. The idea began to be created right after the committing of the crime, but still it is not final and suffers major changes and upgrades.

The mass shooting of the population in Šmarice in October 1941, even during the war, received an aura of martyrdom. After World War II, with the coming of the Communist Party, the event gradually gained a cult status in $\mathrm{Yu}$ goslav World War II history, and the decorated space, museum exhibits and sculptures in the park had the goal of reminding the visitor of the terrible crime committed by the German soldiers against innocent citizens. However, the forming of such clearly defined dogmas rejects any possibility of further critical analysis. Each polemic, especially concerning the number of victims, was received with rejection. Even when it was proven that the number of killed was significantly lower, the public continued to be convinced of the "facts" that had been formed much earlier.

On the other hand, the chronological perspective of the events in Kapislana and Metino Brdo was twofold. The post-war Communist Government emphasized only the Partisan fighters and the victims of fascist terror, although not so grandly, as elsewhere in Serbia. Since the beginning of the 2000s, new research has been carried out and new details about the killings committed after the liberation have been revealed. It was found that hundreds of people were killed in Kapislana and Metino Brdo and public interest, mostly due to media coverage, has shifted from the Nazi crimes to the communist crimes. Unfortunately, everything was stopped at the initial stages of research, so our collective memory is still uneven and is prone to ideological reversals and radical disagreements by individuals. 


\section{REFERENCES}

- Afiero, Massimiliano. The $7^{\text {th }}$ Waffen-SS volunteer gebirgs (mountain) division Prinz Eugen. Atglen: Schiffer Publishing, 2016.

- Avramovski, Živko. Treći Rajh i Borski rudnik. Bor: Muzej rudarstva i metalurgije „Bor“, 1975.

- Begović, Sima. Logor Banjica 1941-1944. 1-2. Beograd: Institut za savremenu istoriju, 1989.

- Beljaković, Miodrag. Pod oblacima Srbije. Kragujevac: Jefimija, 2004.

- Božović, Srđan. Divizija „Princ Eugen “. Pančevo: Narodni muzej, 2011.

- Brkić, Staniša. Ime i broj, Kragujevačka tragedija 1941. Kragujevac: Spomen-park „Kragujevački oktobar“, 2007.

- Brkić Staniša, i Nenad Đorđević. Grosse Vebrechen der Wehrmacht, Kragujevac 1941. Kragujevac: S. Brkić, 2004.

- Browning, Christopher R. "The Final Solution in Serbia-The Semlin Judenlager-A Case Study". Yad Vashem Studies, XV (1983), 55-90.

- Cvetković, Dragan. „Holokaust kao ekstremni oblik stradanja civila okupirane Srbije - numeričko određenje i kvantitativna analiza“. Tokovi istorije, br. 2, (2018), 89-118.

- Cvetković, Srđan. Između srpa i čekića. Represija u Srbiji 1944-1953. Beograd: Institut za savremenu istoriju, 2006.

- Cvetković, Srđan. Komisija za tajne grobnice ubijenih posle 12. septembra 1944. Godišnji izveštaj 2010. Beograd: Državna komisija za tajne grobnice ubijenih posle 12. septembra 1944, Institut za savremenu istoriju, 2010.

- Cvetković, Srđan. Između srpa i čekića, 1. Likvidacija "narodnih neprijatelja” 1944-1953. Beograd: Službeni glasnik, 2015.

- Ćirović, Slobodan. Razgovori u porti pod zapisom. Kragujevac: Nova svetlost, 1995.

- Ćirović, Slobodan. Na tragu zločina. Gruža u četnicima II, 1944-1952. Kragujevac: Nova Svetlost, 2003.

- Dimitrijević, Bojan. Vojska Nedićeve Srbije. Oružane snage Srpske vlade 1941-1945. Beograd: Službeni glasnik, 2014.

- Đorđević, Životije. Gubici stanovništva Jugoslavije u Drugom svetskom ratu. Beograd: ABC-Grafika, 1997.

- Glišić, Venceslav. Teror i zločini nacističke Nemačke u Srbiji 1941-1944. Beograd: Rad, 1970.

- Janjetović, Zoran. Nemci u Vojvodini. Beograd: Institut za noviju istoriju Srbije, 2009.

- Kočović, Bogoljub. Žrtve Drugog svetskog rata u Jugoslaviji. Sarajevo, Svetlost, 1990.

- Koljanin, Milan. Nemački logor na Beogradskom sajmištu 1941-1944. Beograd: Institut za savremenu istoriju, 1992. 
- Kusouris, Dimitris. "From Revolution to Restoration. Transnational Implications of the Greek Purge of Wartime Collaborators", Dealing with Wars and Dictatorships (2014). https://www.academia.edu/5901648/From_Revolution to_Restoration_Transnational_Implications_of_the_Greek_Purge_of_Wartime Collaborators_2014 (accessed August 20, $\overline{2} 01 \overline{8}$ ).

- Lajbenšperger, Nenad. „Presenting and Establishing the Number of Yugoslav Casualties of World War II from Liberation until 1951“. Токови историје, бp. 3, (2017), 143-166.

- Lilić, Jelena. "Comparison between Serbia, Greece and Bulgaria - Trials of Collaborators 1944-1948”. Masterwork, Hugo Valentine Center, Upsala University, 2013.

- Lukač, Dušan. Treći Rajh i zemlje jugoistočne Evrope. Prvi deo, 1933-1936. Beograd, Ljubljana: Vojnoizdavački zavod, Balkanološki institut SANU, Prosveta, Rad-Partizanska knjiga, 1982.

- Lukač, Dušan. Treći Rajh i zemlje jugoistočne Evrope. Drugi deo, 19371941. Beograd, Ljubljana: Vojnoizdavački zavod, Balkanološki institut SANU, Prosveta, Rad-Partizanska knjiga, 1982.

- Lukač, Dušan. Treći Rajh i zemlje jugoistočne Evrope. Treći deo, 1941-1945. Beograd, Ljubljana: Vojnoizdavački zavod, Balkanološki institut SANU, Prosveta, Rad-Partizanska knjiga, 1987.

- Manošek, Valter. Holokaust u Srbiji. Vojna okupaciona politika i uništavanje Jevreja 1941-1942. Beograd: Službeni list SRJ, 2007.

- Micković Evica, i Milena Radojčić, prir. Logor Banjica. Logoraši, prvi tomdrugi tom: knjige zatočenika koncentracionog logora Beograd-Banjica (1941-1944). Beograd: Istorijski arhiv, 2009.

- Mlađenović, Ljubo. Pod šifrom Viking: život, borba i stradanje jugoslovenskih interniraca u logorima u Norveškoj 1942-1945. Beograd: Institut za savremenu istoriju 1991.

- Nikolić, Kosta. Mač revolucije: Ozna u Jugoslaviji: 1944-1946. Beograd: Službeni glasnik, 2016.

- Pajić, Tomislav. Prinudni rad i otpor u logorima Borskog rudnika 19411944. Beograd: Institut za savremenu istoriju, 1989.

- Pavlović Momčilo, i Ivana Pantelić, ur. 27. mart 1941, sedamdeset godina kasnije. Beograd: Institut za savremenu istoriju, 2012.

- Petranović, Branko. Istorija Jugoslavije 1918-1988. II knjiga. Narodnooslobodilački rat i revolucija 1941-1945. Beograd: Nolit, 1988.

- Petranović Branko, i Nikola Žutić, prir. 27. mart 1941, tematska zbirka dokumenata. Beograd: NICOM, 1990.

- Petranović, Branko. Srbija u Drugom svetskom ratu: 1929-1945. Beograd: Vojnoizdavački i novinski centar, 1992.

- Petrović, Dragoljub. Preživeli optužuju. Kragujevac: Spomen park, 1966.

- Ristović, Milan. Nemački novi poredak i Jugoistočna Evropa 1940/411944/45, planovi o budućnosti i praksa. Beograd: Službeni glasnik, 2005. 
- Ristović, Milan. „Nacistička dominacija u istočnoj i jugoistočnoj Evropi 1939-1945: okupacija, aneksija, saveznički sistem“. Nastava i istorija: časopis prosvetnih radnika, god. V, br. 7 (2007), 17-45.

- Terzić, Velimir. Slom Kraljevine Jugoslavije 1941. Uzroci i posledice poraza, 2. Beograd, Ljubljana-Beograd, Titograd: Narodna knjiga-Partizanska knjiga-Pobjeda, 1982.

- Tomanić, Boris. „Kragujevački oktobar na Nirnberškom procesu“, Godišnjak za istraživanje genocida 8 (2016), 229-252.

- Zbornik dokumenata i podataka o narodno-oslobodilačkom ratu jugoslovenskih naroda, tom 1, knjiga 1. Beograd: Vojnoistorijski institut Jugoslovenske narodne armije, 1949.

- Zbornik dokumenata i podataka o narodno-oslobodilačkom ratu jugoslovenskih naroda, tom 1, knjiga 2. Beograd: Vojnoistorijski institut Jugoslovenske narodne armije, 1952.

- Zečević Ljubomir, i Tamara Ćirić, Koncentracioni logor Mauthauzen povratak nepoželjan. Beograd: Udruženje zatočenika KL Mauthauzen Srbije, 2015.

- Zirojević, Željko. Mart 1942. g. Streljanje antifašista. Metino brdo-Medna. Kragujevac: SUBNOR, 2012.

- Žerjavić, Vladimir. Gubici stanovništva Jugoslavije u Drugom svjetskom ratu. Zagreb: Jugoslavensko viktimološko društvo, 1989.

- Živković, Nikola. Ratna šteta koju je Nemačka učinila Jugoslaviji u Drugom svetskom ratu. Beograd: Institut za savremenu istoriju, 1974. 
BORIS TOMANIĆ, MA, Research Assistant

Institute for Contemporary History

Belgrade, Republic of Serbia

borisbox62@gmail.com

\title{
MASS SHOOTINGS IN KRAGUJEVAC DURING \\ AND AFTER WORLD WAR II (1941-1945) \\ TESTIMONIES AND MEMORIZATION
}

\begin{abstract}
Summary
The article analyzes three of the most famous killing fields in Kragujevac and its surroundings - Šumarice, Metino Brdo and Kapislana. In these locations during the occupation of Yugoslavia, German soldiers executed civilians and members of the resistance movements. After the liberation of Serbia in the autumn of 1944, the new communist government began with shootings in the same locations through its military and police institutions. In the wild justice and uncontrolled retributions, a large number of civilians-ideological enemies were killed. The perception, method, and the frequency of crimes and level of repression are described through the testimonies of the survivors. Also outlined is the parallel between criminals and victims.

The continuity of the crimes that lasted with minor interruptions from October 1941 to the spring of 1945, the large number of those who were killed and the different executors of mass crimes led to the shaping of collective memory in the most tragic form that, over time, suffered numerous changes and additions. Due to political and social aspects, as well as uncritical perceptions of the past, the memorization has remained disproportionate. At the beginning of the 21 st century, new efforts have been made in studying the crimes, especially those in which the perpetrators were the institutions of the communist government. Unfortunately, scientific procedures are still in their initial phase, so, as already stated, the collective memory is still uneven and prone to ideological turnarounds and radical disagreements among individuals.
\end{abstract}

KEYWORDS: Kragujevac, Serbia, World War II, German Soldiers, Communist Authorities, Mass Shootings 